\title{
Cytoskeleton-Associated Protein 5
}

National Cancer Institute

\section{Source}

National Cancer Institute. Cytoskeleton-Associated Protein 5. NCI Thesaurus. Code

C119706.

Cytoskeleton-associated protein 5 (2032 aa, $225 \mathrm{kDa}$ ) is encoded by the human CKAP5 gene. This protein is involved in mitotic spindle organization. 